УДК 621.59

V. V. Trandafilov $\bowtie$, M. G. Khmelniuk, O. Y.Yakovleva, A. V. Ostapenko

Odessa National Academy of Food Technologies, 112 Kanatnaya str., Odessa, 65039, Ukraine

$\bowtie$ vlad.trandafilov@gmail.com, https://orcid.org/0000-0001-9905-9958

\title{
THE STIRLING GAS REFRIGERATING MACHINE MECHANICAL DESIGN IMPROVING
}

To improve the mechanical design of the piston Stirling gas refrigeration machine the structural optimization of rotary vane Stirling gas refrigeration machine is carried out. This paper presents the results of theoretical research. Analysis and prospects of rotary vane Stirling gas refrigeration machine for domestic and industrial refrigeration purpose are represented. The results of a patent search by mechanisms of transformation of rotary vane machines are discussed.

Keywords: Stirling gas refrigerating machine - Rotary-vane machine - Conversion mechanism - Mass and size characteristics

В.В. Трандафілов, М. Г. Хмельнюк, О. Ю. Яковлева, О. В. Остапенко

Одеська національна академія харчових технологій, вул. Канатна, 112, Одеса, 65039, Україна

\section{ВДОСКОНАЛЕННЯ КОНСТРУКЦІЇ ГАЗОВОЇ ХОЛОДИЛЬНОЇ МАШИНИ СТІРЛІНГА}

Для вдосконалення конструкиії поршневої газової холодильної машини Стірлінга проведена структурна оптимізація роторно-лопатевої газової холодильної машини. У даній роботі викладені результати теоретичних досліджень. Показано перспективи використання роторнолопатевої машини для побутової та промислової холодильної техніки. Приведено результати патентного пошуку за механізмами перетворення роторно-лопатевих машин.

Ключові слова: Газова холодильна машина Стірлінга - Роторно-лопатева машина - Механізм перетворення - Масогабаритні характеристики.

This work is licensed under the Creative Commons Attribution International License (CC BY). http://creativecommons.org/licenses/by/4.0/

\section{INTRODUCTION}

At the present time refrigeration machines that are used natural working medium as refrigerants become increasingly important. For this reason Stirling cycle refrigeration get topical priority.

Working fluids of Stirling gas refrigeration machine are eco-friendly substances (helium, hydrogen, nitrogen, air)which fully meet the requirements of the Montreal Protocol (ozone-depleting substances) and the Kyoto Protocol (greenhouse gas emissions) [1].However in practice only three working fluids are of interest: air, helium and hydrogen. Air attracts with its availability. Helium and hydrogen are of concern with regard to their thermodynamic properties, namely those which allow to have high coefficients of heat transfer and to provide a gas flow with relatively low pressure drop.

The design of the compressor unit Stirling gas refrigeration machine are based on the reciprocating motion of the pistons, sold through a crank mechanism (CSV) or by means of a linear actuator. For achieving the tightness chambers it requires the installation of the contact seal in the case of CSV use, and "contactless" pistons, which are part of the linear actuator, is achieved by increasing the complexity of mechanical design of these machine, that in own turn [2].This complexity of the system of cranks and levers, piston Stirling gas refrigeration machine, along with other reasons, restricts their increased use.
To improve the design of the piston Stirling gas refrigeration machine structural optimization rotary vane gas refrigeration machine is carried out.

As an option for refrigeration machine which working by a Stirling cycle is rotary-vane machine. With less system elements, better balance and more simple manufacturing techniques using cause of a cylinder form of rotary vane machines are capable to be more preferable direction in Stirling refrigeration machines improvement. The mechanical design of rotary vane gas refrigeration machine (RVGRM) is shown on Figure 1. Workspace of RVGRM, in which the processes of compression and expansion occurs, is represented as an annular cavity of variable volume (rectangular for example), inside which oscillates like a movement of scissors, two pairs of vanes, performing the function of pistons.

Closed volume of each of the four working chambers is created between the fixed walls of the corpus and two moving vanes of rotational-vibrational movement relative to the corpus. Four-chamber RVGRM workflow is arranged in such way that rotation of the outer propeller shaft has a constant velocity, it transmits the rotation motion converting mechanism which converts the rotational movement of the shaft in a rotationally oscillating motion of the vanes. At this time, in one pair of working chambers occurs the process of compression and discharge, in the other pair of working chambers - the process of suction and expansion. Suction and discharge of 
the working fluid is made through the holes located in places on the corpus where the vanes meet.

The limiting factor of rotary vane machines widespread is the lack of a reliable durability. One of the problematic parts of such units is a conversion mechanism that allows the blades movement according to a given law.

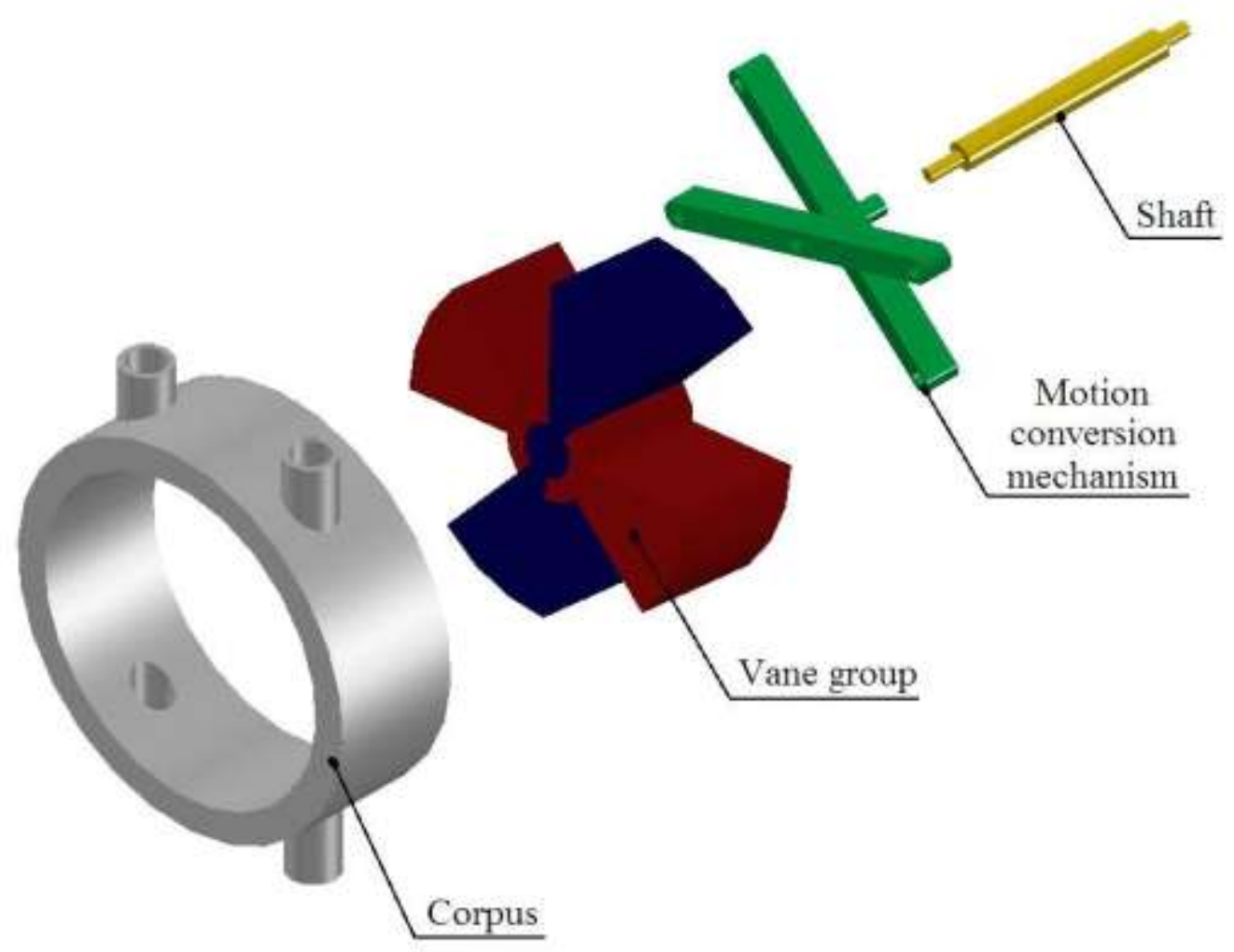

Figure 1 - The mechanical design of RVGRM.

\section{CONVERSION MECHANISMANALYSIS}

Nowadays it is possible to talk about specific areas of mechanical engineering, in which there are certain achievements in the use of the rotary-vane constructions [3]. An analysis of patent activity in recent years has shown that one of the most promising in terms of meeting the evaluation criteria is a four-bar lever-motion converting cam mechanism (Fig 2) [4].
The aim of the proposed device is to improve the reliability of the machine by increasing the fluidity of movement of the pistons through the use of a cam mechanism for converting movement in which there is no complex gears, increased COP through more compact version of the working chambers and reducing the length of the pipeline, as well as providing the possibility of adjusting the momentum on the output shaft of the machine.

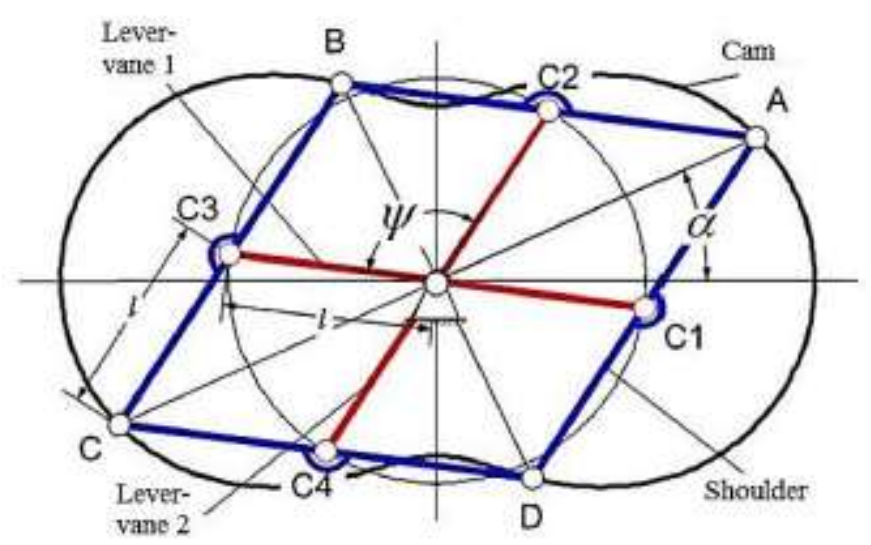

Figure 2 - Four-lever-cam mechanism. 
The mechanism includes a quadric and a cam. It consists of four sections of pivotally connected arms of equal length $L=21$ ( $\mathrm{AB}, \mathrm{BC}, \mathrm{CD}, \mathrm{DA})$. By the middle of shoulders the levers are mounted (C1-C2 and C3-C4).

As the main angle for calculation the angle of rotation $\alpha$ between the diagonal AC and the $\mathrm{x}$-axis is accepted. The most important parameter of the kinematic mechanism is the angle between the arms (C1-C3 and C2-C4) $\psi$. This angle changes in stages:

$$
\psi_{\min } \leq \psi \leq \psi_{\max }, \psi_{\max }=\pi-\psi_{\min },
$$

where the values of the maximum and minimum values of the angle $\psi_{\max }$ and $\psi_{\min }$ set from the design considerations.

Profile of the cam is an equidistant, spaced by the value of the thumb radius of the inside by the base closed curve described by the following formula:

$$
\rho(\alpha)=L \cdot \sin \left(\frac{\pi}{4}+\left(\frac{\pi}{4}-\frac{\psi_{\min }}{2}\right) \cdot \cos 2 \alpha\right),
$$

where $\rho(\alpha)$ - polar radius; $\alpha=0 \ldots 2 \pi$ - polar angle; $L-$ the length of the side of rhomboid quadric; $\psi_{\min }-$ minimal angle between the rhomboid quadricsides; $\pi-\mathrm{Pi}$.

In [5], the results support the need of further research for a more optimal angle between the arms, and hence the cam profile. Choosing the best law is multifactorial. For solving it is necessary to perform kinematic, strength and dynamic research. However, if any other of the cam profile, not belonging to the equidistant family and the other placing fingers on the rhomb and the location on the disk guiding the transformation of the move- ment will be accompanied by spurts and blows (violation of smoothness). Also non-variable execution of mechanism is rather complicated structure, with the relative complexity of a large number of non-standard components manufacturing which reduces the advantages of the known device. In connection with this the further refinement of the mechanism is required and decision about the task to change the shape of the cam.

The conversion mechanisms are also known, comprising a corpus, a drive shaft, a second hollow shaft mounted coaxially to the drive shaft and a node of the motion conversion. According to the invention, the assembly transformation is executed in the form specified in the corpus coaxially to the shafts disc centered is executed shaped raceway between which and the hollow shaft has an even number of rollers, half of which rotate around its own axis and crosswise in pairs and rigidly connected through brackets with master and second shafts, and the rest are arranged freely between the rollers and rigidly associated paths, wherein the drive shaft is the power take-off shaft. Thus, we reduce capital costs of production which is reflected in the unit cost of the product. Design of the converting mechanism is shown in Fig. 3 [6].

The technical result to increase reliability and COP is achieved by simplification of the mechanism, the cam conversion, reducing the number of associated components of the machine, which thereby reduces the wear of these surfaces and reduces the mechanical losses in the machine. Workability improved by using substantially standard components manufactured in much smaller amounts than in known solutions.

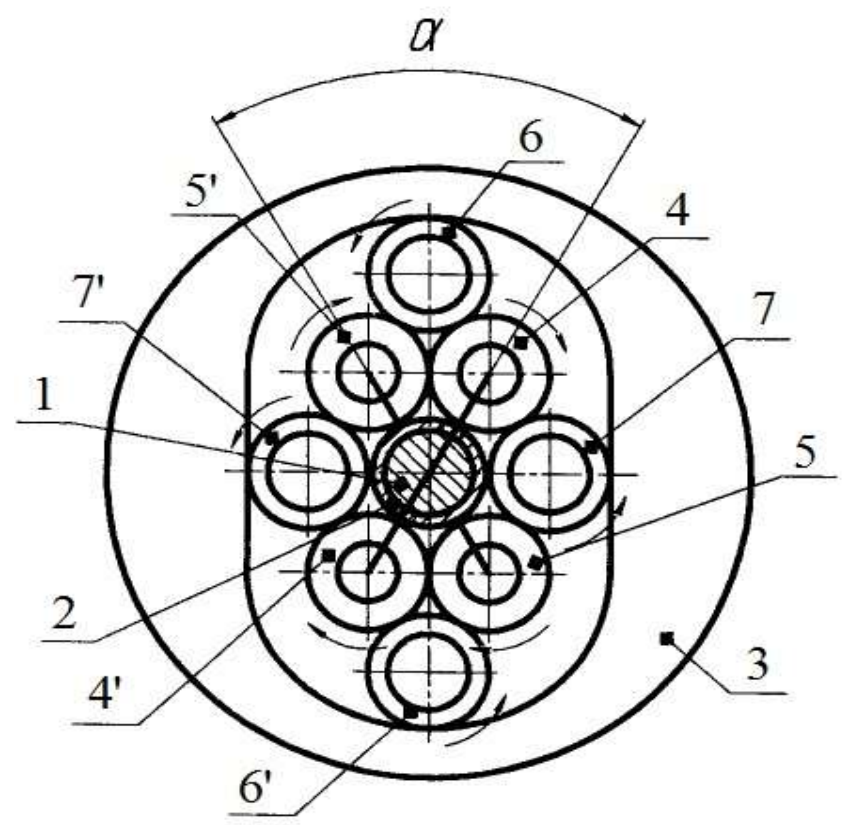

Figure 3 - The movement conversion mechanism.

1 -drive shaft; 2 -driven shaft; 3 - disc with profiled path;

4-4 ', 5-5', 6-6 'and 7-7' - rollers; $\alpha$ - angle between the rollers. 


\section{INFLUENCE OF DESIGN STRUCTURAL MODIFICATIONON ENERGY EFFICIENCY OF STIRLING GAS REFRIGERATION MACHINE}

Taking into account all of these perspectives of rotary vane machines to piston machines it is necessary to make the main emphasis on the comparison of power, and mass-size parameters of RVGRM to conventional piston Stirling gas refrigeration machine. The comparison results are shown in Table 1 [7].
Comparative analysis of gas refrigeration machine parameters shows the advantage of energy characteristics by $30 \%$ and $20 \%$ of mass characteristics in the case of RVGRM. Through reciprocating oscillatory motion of the vanes (as opposed to a reciprocating piston machines) and to reduce friction losses in the working chambers operating on the gaps of RVGRM potentially has long service life considerably compared with piston machines.

Table 1 - Comparison of RVGRM and piston GRM

\begin{tabular}{|c|c|c|}
\hline Technical performance & RVGRM & GRM \\
\hline Specific mass, $\mathrm{kg} / \mathrm{kW}$ & 3,00 & 3,63 \\
\hline COP & 2,21 & 1,70 \\
\hline The maximum rotational speed, rev/min & 60 & $800-1000$ \\
\hline Mechanical friction losses, $\%$ & 10 & 35 \\
\hline The average speed of the vane (piston) group, $\mathrm{m} / \mathrm{s}$ & $30-50$ & $15-25$ \\
\hline The amplitude of vibration (in limbo), micron & 100 & 3000 \\
\hline
\end{tabular}

Compactness coefficient of RVGRM main volume (the ratio of working volume equivalent to the volume of the machine) reaches $15-20 \%$, while the maximum value of this parameter for the piston gas refrigeration machine (V - shaped with a crank) is $1-2 \%$. Such a large (several times) benefit of the specific mass indicators opens up prospects for the use of this type machines. It gives us the opportunity to use rotary vane machines for domestic refrigeration appliances. Figure 4 shows the mass prop- erties of RVGRM as well as the characteristics of experimental and production models of single and two-stage Stirling gas refrigeration machine. It is evident that according to V.M.Brodyansky the parameters of RVGRM lie at the lower end zones efficiency [7]. This indicates RVGRM perfectly comparable with the experimental and serial Stirling machines. This in turn proves the possibility of RVGRM use for domestic refrigeration appliances.

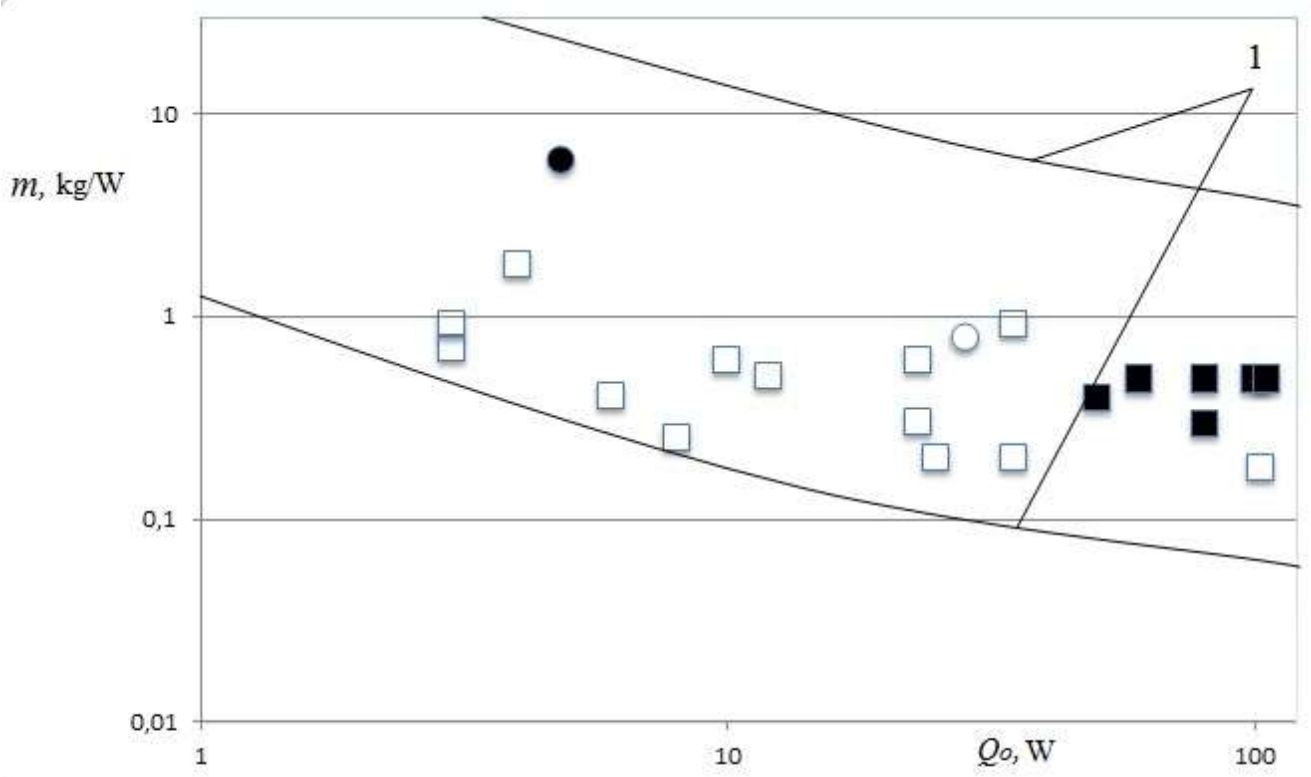

Figure 4 - Mass Properties Stirling refrigerator.

口- single stage Stirling refrigerator; - two-stage Stirling refrigerator;

o- single stage RVGRM; •-two-stage RVGRM.

1 - area of mass characteristics efficiency. 
On the basis of previous studies and to identify problems in the field of high-performance piston Stirling gas refrigeration machine, requirements for modern rotary vane machines working on Stirling cycle are in the optimal design of the basic units. This synthesis was the result of a thorough analysis of contemporary design options machine with identifying advantages and disadvantages of each.

Innovative aspect and the expected prospects RVGRM require the development of experimental samples and conducting leading research of physical processes in the simulation environment, as well as attracting of mathematical modeling and research on special stands, required when creating and testing new consumer and industrial refrigeration.

Thus, the success of creating a globally competitive rotary vane Stirling gas refrigeration machine can be achieved only as a result of the synthesis of high-level scientific research, rigorous constructive study of the basic units RVGRM and advanced production technology.

\section{CONCLUSIONS}

Our proposed solution for improving the mechanical design of RVGRM can achieve higher values of the main indicators of the requirements for piston gas refrigeration machine, the main of which is to reduce the weight and size characteristics by $20 \%$. This in turn makes it possible to achieve energy efficiency increase by $30 \%$. Based on this standardization and unification of the machine design through the use of mass-produced parts the degree of design and process continuity can be increased. With a decrease in the number of associated components increase the reliability achieved by $5 \%$. The use of natural working fluids reduces the harmful impact on the environment.

Improving the design of Stirling gas refrigeration machine enables us to go to its widespread use, ignoring the drawbacks to use rotary-piston gas refrigeration units for domestic and industrial applications.

\section{REFERENCES}

1. Trandafilov V. V., Yakovleva O. Y., Khmelniuk M.G. 2015. Medium-temperature Stirling refrigeration system trends. Refrigeration engineering and technology, 51(3), 26-33.

doi: 10.15673/0453-8307.3/2015.38075

2. Kolomin I. V. e.a. 2009. Rotor-vane compressor with working chambers contactless condensation optimizations variants. Vestnik SSAU, No 3.

3. Grinev D. V. 2014. Constructive schemes and principles of operation of the rotor-blade machines. Vestnik Pskov SU, No 5.

4. Lukjanov Ju. N., e.a. Mechanism for movement transformation Patent. RU No. 2374526, 2009.

5. Grinev D. V. 2013. About variation of the angle between the levers of the cam-and-lever mechanism. Vestnik Pskov SU, No 2.

6. Sosin S. S. Movement conversion mechanism. Patent RU No 2531854, 2014.

7. Kolomin I. V., Krasnochub E. K. 2010. Rotor-Vane Cryogenic Cooling Machine Investigations. Journal Polet. No 4.

Received 06 October 2015 Approved 18 December 2015 Available in Internet 28.02 .2016

В. В. Трандафилов, М. Г. Хмельнюк, О. Ю. Яковлева, А. В. Остапенко

Одесская национальная академия пищевых технологий, ул. Канатная, 112, Одесса, 65039, Украина

\section{УСОВЕРШЕНСТВОВАНИЕ КОНСТРУКЦИИ ГАЗОВОЙ ХОЛОДИЛЬНОЙ МАШИНЫ СТИРЛИНГА}

Для усовершенствования конструкичи поршневой газовой холодильной машинь Стирлинга проведена структурная оптимизация роторно-лопастной газовой холодильной машины. $B$ данной работе изложены результаты теоретических исследований. Показаны перспективы использования роторно-лопастной машины для бытовой и промышленной холодильной техники. Приведены результаты патентного поиска по механизмам преобразования роторнолопастных машин.

Ключевые слова: Газовая холодильная машина Стирлинга - Роторно-лопастная машина Механизм преобразования - Массогабаритные характеристики. 